\title{
Microstructural and optical properties of CSS and CBD-CdS thin films for photovoltaic solar cells
}

Leila Rosa Cruz ${ }^{1}$, José Antônio Sousa Fernandes ${ }^{1}$, Carlos Luiz Ferreira ${ }^{1}$, Wagner Anacleto Pinheiro ${ }^{1}$

\author{
${ }^{1}$ Military Institute of Engineering, Materials and Mechanical Engineering Department, Praça General Tibúrcio, 80 - Urca, \\ 2290-270 - Rio de Janeiro, RJ \\ e-mail: leilacruz@ ime.eb.br; jasousa@superig.com.br; cferreira@ime.eb.br; anacleto@ ime.eb.br
}

\begin{abstract}
This work compares the properties of CdS films deposited by CBD and CSS techniques. The influence of the deposition parameters on the properties of the films was investigated. The thickness of CBD films ranged from 80 to $100 \mathrm{~nm}$ and was affected by the concentration of reactants in the solution. For CSS films, the thickness was controlled in the 100-300nm range, being strongly influenced by the source/substrate temperatures and pressure. Grain size in CSS films was larger than in CBD films. Transmittance of CBD and CSS films ranged from 80 to $90 \%$, but the band gap in CSS films was narrower than in CBD films, which means that CSS films transmit less of the blue part of the solar spectrum than CBD films. However, the growth of CdS films by CSS technique may be advantageous because the CdS/CdTe device could be fully manufactured in the same system.
\end{abstract}

Keywords: CdS thin films; CBD deposition; CSS deposition; microstructure; optical properties.

\section{INTRODUCTION}

Cadmium sulfide (CdS) is the wide bandgap material used in cadmium telluride (CdTe) heterojunction solar cells. Currently, the CdS/CdTe technology dominates the thin-film photovoltaic market, followed by thinfilm silicon and copper-indium-gallium arsenide technologies, and the global production surpasses $2 \mathrm{GWp}$ [1]. Recently, GE reported a 19.6\% CdTe cell in laboratory scale and First Solar claimed a module efficiency of $16.1 \%$ [2]. Since CdS is the window of this photovoltaic junction, it must be made very thin - usually 100 $\mathrm{nm}$ thick - to guarantee that most of the incident light crosses the junction and impinges the CdTe absorber layer, promoting high photocurrent. Besides being thin, this film must also be continuous, to prevent short circuit in the cell. The chemical bath deposition (CBD) of CdS films can meet these requirements very well [3-6]. CBD-CdS films are grown by decomposition of thiourea (the source of $\mathrm{S}$ ) in an alkaline solution, in the presence of $\mathrm{Cd}^{2+}$ ions. The advantages of this technique are the low cost of the process and the presence of oxygen in the solution, which is naturally incorporated into the film, improving the device performance []]. A technological concern is the disposal of the large quantity of residues resulting from the process. CdS thin films have also been grown by the close spaced sublimation (CSS) technique [6-8]. CSS-CdS films are grown in low vacuum regime, by sublimating a $\mathrm{CdS}$ source separated from the substrate by very small distances, usually few millimeters. In this configuration the films are deposited at temperatures close to the source temperature at high deposition rates. Due to the high substrate temperatures, grain size in CSS films is larger than in CBD films. However, as CSS is a high rate deposition technique, it is difficult to get very thin films using this process. In this case, the control of some parameters, such as pressure and source/substrate temperatures, is essential for obtaining continuous films. The main advantage of the CSS process is that the whole $\mathrm{CdS} / \mathrm{CdTe}$ device can be manufactured inside the same system, without breaking vacuum, minimizing the costs in a production line. In this work, the properties of CBD and CSS-CdS thin films are compared in order to evaluate which one is more adequate for being used in $\mathrm{CdS} / \mathrm{CdTe}$ solar cells. 


\section{EXPERIMETAL METHOD}

CdS films were deposited by CBD and CSS onto borosilicate substrates covered with a bilayer of transparent conductive oxides: fluorine doped tin oxide/undoped tin oxide $\left(\mathrm{SnO}_{2}: \mathrm{F} / \mathrm{SnO}_{2}\right)$ - supplied by the National Renewable Energy Laboratory (NREL).

CBD-CdS films were prepared by first immersing the abovementioned substrates in a beaker containing $137.5 \mathrm{ml}$ of DI water heated at $90^{\circ} \mathrm{C}$. Then, the reactants were introduced. Firstly, $2 \mathrm{ml}$ of cadmium acetate $\left[\mathrm{Cd}\left(\mathrm{CH}_{3} \mathrm{COO}\right)_{2}\right], 0.033 \mathrm{M}$, and $1.2 \mathrm{ml}$ of ammonium acetate $\left(\mathrm{NH}_{4} \mathrm{CH}_{3} \mathrm{COO}\right), 1.0 \mathrm{M}$, were added. The cadmium acetate was the source of $\mathrm{Cd}$ and the ammonium acetate acted as a buffer solution, controlling the reaction rate. After $4 \mathrm{~min}$, droplets of ammonia $(3.7 \mathrm{M})$ were added very slowly in order to adjust the $\mathrm{pH}$ of the solution at 9. After that, $0.5 \mathrm{ml}$ of thiourea $\left[\mathrm{CS}\left(\mathrm{NH}_{2}\right)_{2}\right], 0.067 \mathrm{M}$, was introduced every 10 min up to a total of $2 \mathrm{ml}$. The concentration of reactants in the solution was changed by doubling and tripling this volume of reactants, hereafter $V_{R}$, while keeping constant the volume of water. The total deposition time, after the addition of the first portion of thiourea, was $40 \mathrm{~min}$. The substrates were then removed from the bath and rinsed in warm DI water.

CSS-CdS films were deposited in a homemade equipment composed of a quartz tube into which two graphite blocks, separated by a distance of $2 \mathrm{~mm}$, were inserted to sustain the source and substrate. The graphite blocks, heated by halogen lamps, were used to homogenize the temperatures of the source and substrate. The CdS source was a $35 \mu \mathrm{m}$ thick CdS layer deposited onto a borosilicate substrate. This source-plate was prepared by sublimating a CdS/propyleneglycol paste. Details about the equipment can be seen elsewhere [9]. The pressure of the system was varied between 5 and 15 Torr, using argon or a mixture of oxygen/argon.

Film thicknesses were measured in a Dektak 150 surface profiler from Veeco. X-ray diffraction (XRD) analyses were made on a Siemens D5000 diffractometer with a $\mathrm{Cu}$ anode. Grazing incidence mode was selected due to the small thickness of the films. The incidence angle was fixed at $1^{\circ}$ and the scans were taken between $20^{\circ}$ and $80^{\circ}$ at $0.02^{\circ} \mathrm{s}^{-1}$. Optical transmittance spectra were obtained in a Cary 5000 spectrophotometer from Varian. Morphology was evaluated by atomic force microscopy (AFM) in a Veeco SPM DI3100 microscope.

Solar cells using CBD and CSS-CdS films were fabricated in the CSS system with the configuration glass $/ \mathrm{SnO}_{2} / \mathrm{CdS} / \mathrm{CdTe} /$ back-contact using the procedures described elsewhere [10]. Briefly, a 5-7 $\mu \mathrm{m}$ thick CdTe film was deposited onto glass $/ \mathrm{SnO}_{2} / \mathrm{CdS}$ structures. The source and substrate temperatures for $\mathrm{CdTe}$ deposition were 610 and $480^{\circ} \mathrm{C}$, respectively, and the argon pressure was 1 Torr. The devices were finished according to the following procedures: the CdTe surface was submitted to a heat treatment in air (100 Torr), in the presence of a saturated $\mathrm{CdCl}_{2}$ solution, at $380{ }^{\circ} \mathrm{C}$, for $30 \mathrm{~min}$; after that, the $\mathrm{CdTe}$ surface was etched with a nitric/phosphoric acid, and then gold was evaporated for the back contact. The efficiency was measured in a system composed of a solar Simulator, model 81160-1000-1, from Oriel Instruments, a Xe/ $\mathrm{HgXe}$ arc lamp (200-500 Watts), and a 3 A current source, model 2420, from Keithley.

\section{RESULTS}

Table 1 shows the thickness of CBD-CdS films deposited from solutions with different concentrations of reactants (the concentration increases with the volume of reactants, $V_{R}$ ). As expected, the thickest film was the one grown from the most concentrated solution, $3 \mathrm{~V}_{\mathrm{R}}$, since a larger number of $\mathrm{Cd}^{2+}$ and $\mathrm{S}^{2-}$ ions was available. It was found that this film had the proper thickness for manufacturing $\mathrm{CdS} / \mathrm{CdTe}$ solar cells, which must be less than $100 \mathrm{~nm}[7]$.

Table 2 shows the thickness of CSS-CdS films deposited at different conditions. The deposition rate was calculated as the ratio of the thickness to the deposition time. The deposition time required to get 100$300 \mathrm{~nm}$ CSS films was considerably shorter than the $40 \mathrm{~min}$ spent in CBD technique, which represents a huge advantage. Both the increase of the source temperature and the decrease of the pressure led to an enhancement of the deposition rate, an expected result given that the transport mechanism in CSS technique is controlled by the diffusion of the molecules from the source to the substrate [11]. The introduction of oxygen in the gaseous mixture deeply decreased the deposition rate. Unlike argon, oxygen is expected to react with $\mathrm{Cd}$ vapor species impairing the effectiveness of their transport from the source to the substrate, and then decreasing the deposition rate. Some authors have already observed the same effect in cadmium telluride thin films. They showed that a small amount of oxygen in the gaseous atmosphere reduced the deposition rate by half of the initial value [12]. In spite of this, it is generally agreed that oxygen plays an important role in the production of efficient devices $[\underline{6}, \underline{12}]$. 
Table 1: Thickness of CBD-CdS thin films as a function of the volume of reactants. $V_{R}=2 \mathrm{ml}$ of cadmium acetate, 1.2 $\mathrm{ml}$ of ammonium acetate, and $2 \mathrm{ml}$ of thiourea.

\begin{tabular}{c|c|c}
\hline SAMPLE & VOLUME OF REACTANTS & THICKNESS (nm) \\
\hline 1 & $1 \mathrm{~V}_{\mathrm{R}}$ & 49 \\
\hline 2 & $2 \mathrm{~V}_{\mathrm{R}}$ & 58 \\
\hline 3 & $3 \mathrm{~V}_{\mathrm{R}}$ & 105 \\
\hline
\end{tabular}

Table 2: Thickness and deposition rate of CSS-CdS thin films as a function of: source temperature $\left(\mathrm{T}_{\mathrm{sc}}\right)$, substrate temperature $\left(\mathrm{T}_{\mathrm{sub}}\right)$, argon pressure $\left(\mathrm{P}_{\mathrm{Ar}}\right)$, and oxygen pressure $\left(\mathrm{P}_{\mathrm{O} 2}\right)$. Source-substrate distance was $2 \mathrm{~mm}$.

\begin{tabular}{l|c|c|c|c|c|c|c}
\hline \multicolumn{1}{c|}{ SAMPLE $^{\star}$} & $\begin{array}{c}\mathbf{T}_{\mathbf{s c}} \\
\left({ }^{\circ} \mathbf{C}\right)\end{array}$ & $\begin{array}{c}\mathbf{T}_{\text {sub }} \\
\left({ }^{\circ} \mathbf{C}\right)\end{array}$ & $\begin{array}{c}\mathbf{P}_{\text {Ar }} \\
(\text { Torr })\end{array}$ & $\begin{array}{c}\mathbf{P}_{\text {O2 }} \\
(\text { Torr) }\end{array}$ & $\begin{array}{c}\text { DEPOSITION } \\
\text { TIME (s) }\end{array}$ & $\begin{array}{c}\text { THICKNESS } \\
(\mathbf{n m})\end{array}$ & $\begin{array}{c}\text { DEPOSITION } \\
\text { RATE (nm/min) }\end{array}$ \\
\hline $660-540-15-0$ & 660 & 540 & 15 & 0 & 240 & 190 & 48 \\
\hline $660-540-5-0$ & 660 & 540 & 5 & 0 & 120 & 207 & 104 \\
\hline $660-540-5-2$ & 660 & 540 & 5 & 2 & 120 & 170 & 85 \\
\hline $670-550-5-0$ & 670 & 550 & 5 & 0 & 100 & 235 & 141 \\
\hline $670-550-5-2$ & 670 & 550 & 5 & 2 & 100 & 87 & 52 \\
\hline
\end{tabular}

* The number describes the parameters used during the sample deposition $\left(\mathrm{T}_{\mathrm{sc}}-\mathrm{T}_{\mathrm{sub}}-\mathrm{P}_{\mathrm{Ar}}-\mathrm{P}_{\mathrm{O} 2}\right)$

Figure 1 shows AFM images of the surface of CBD-CdS films grown from solutions with different volume of reactants. The morphology in both films is quite similar, composed of agglomerates of nanograins. These agglomerates contributed to the surface roughness, which was evaluated by the root mean-square value $(\mathrm{Rq})$, typically $8 \mathrm{~nm}$, as given by AFM analyses. This is an acceptable value for the $100 \mathrm{~nm}$-thick films. Figure 2 shows AFM images of the surface of CSS-CdS films. The grains are bigger than in CBD-CdS films due to the higher deposition temperature. The morphology was strongly affected by the source/substrate temperatures, pressure, and presence of oxygen. The bigger grains in Fig. 2 a were due to the lower deposition rate obtained for the films grown at higher pressures, as shown in Table 2. Figure 2c shows that the presence of oxygen in the gaseous mixture favored the growth of denser films with a better coverage, an important requirement for their application in heterojunction solar cells. The Rq roughness values ranged from 20 to 32 $\mathrm{nm}$, as given by AFM analysis, and were greater than those found in CBD films due to the bigger grains in CSS films. It should also be noted that the roughness decreased when the films were deposited in the presence of oxygen, certainly due to the denser microstructure. A similar result has been found in the literature for CdTe films [12].

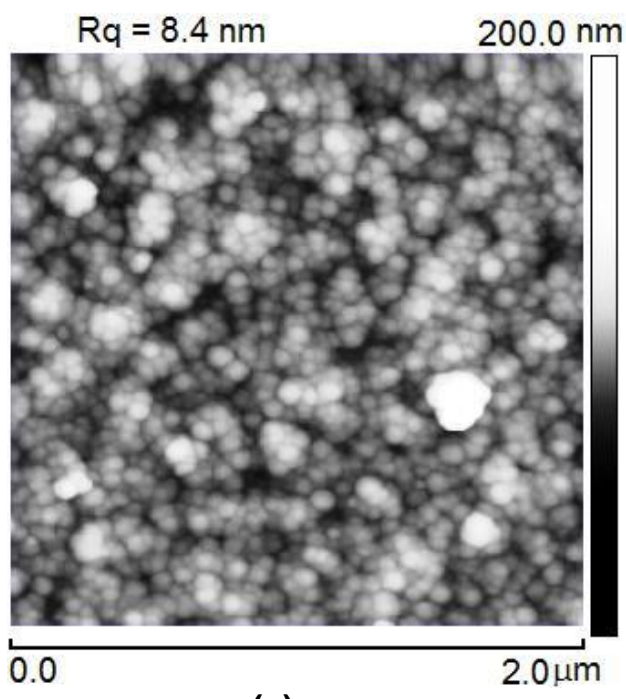

(a)

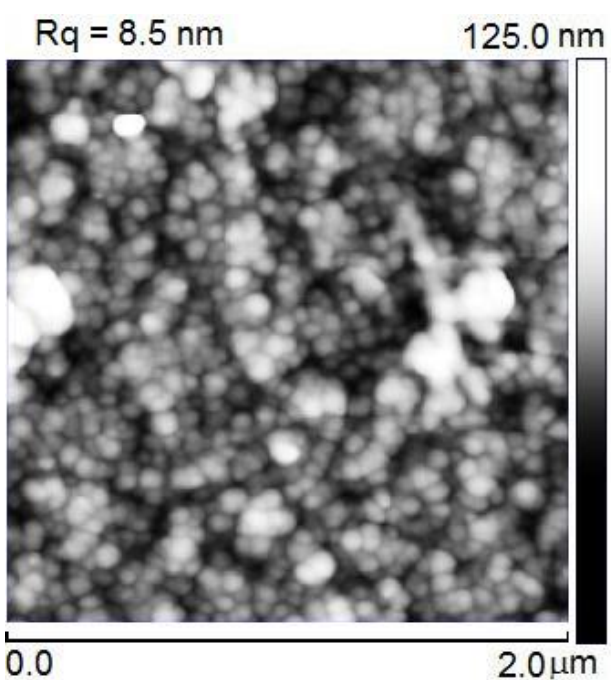

(b) 
Figure 1: AFM images of the surface of CBD-CdS films grown from solutions with different volumes of reactants: a) $\mathrm{V}_{\mathrm{R}}$; b) $3 \mathrm{~V}_{\mathrm{R}}$.

Grazing incidence diffractograms of CBD films are not shown here, as only a very low intensity (220) diffraction peak, from the CdS cubic phase, was hardly identified, confirming that the films were nanocrystalline. On the other hand, due to the higher deposition temperatures, most of the CSS-CdS films were crystalline, being predominantly composed of the hexagonal phase, as depicted in Fig. 3. It can also be observed that the presence of oxygen impaired the crystallinity of these films.

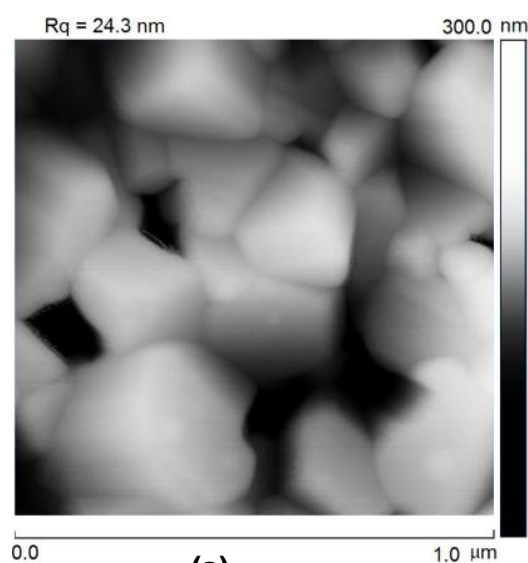

(a)

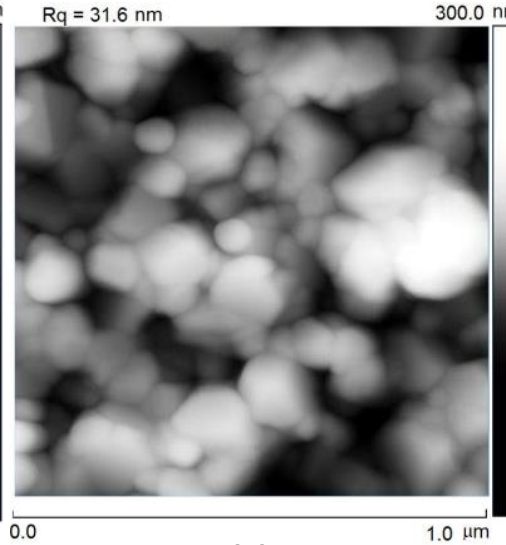

(b)

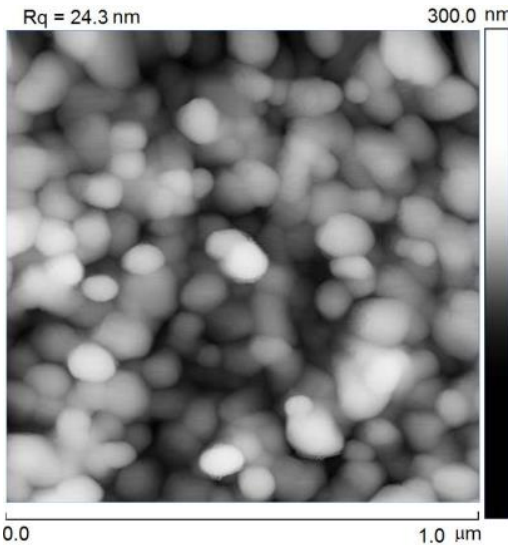

(c)

Figure 2: AFM images of the surface of CSS-CdS films grown at different conditions: a) 660-540-15-0; b) 670-550-5-0; c) $670-550-5-2$

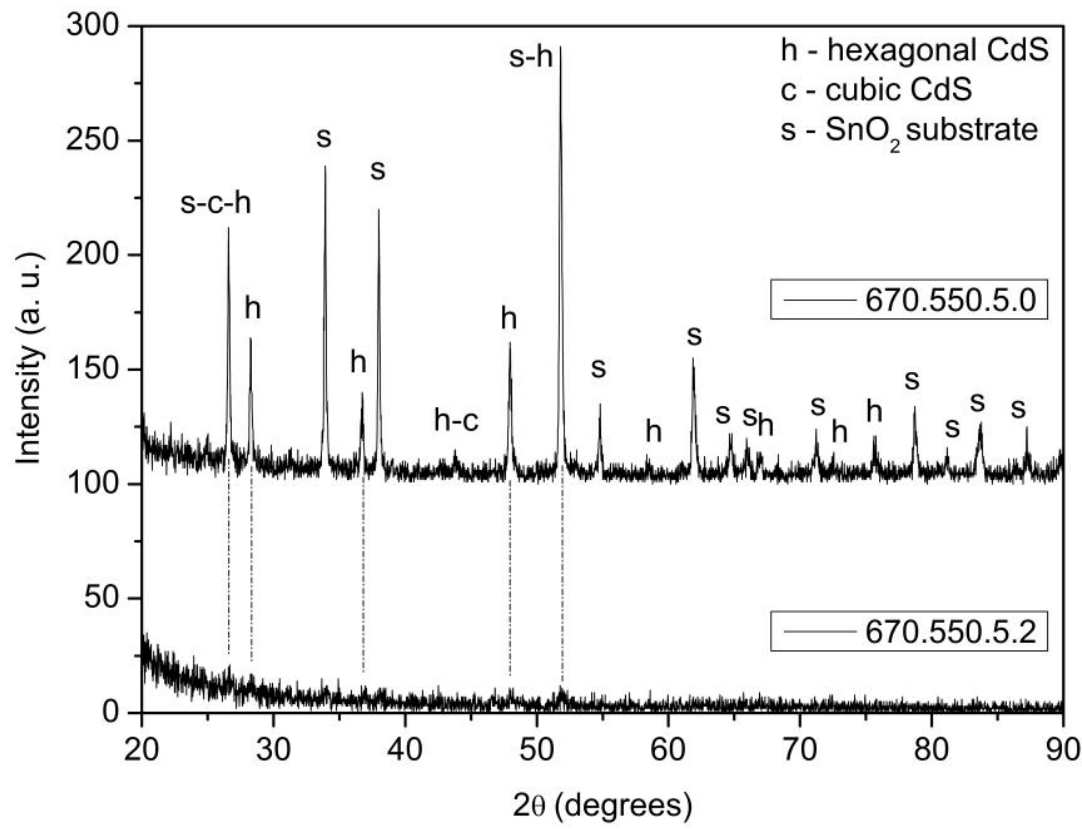

Figure 3: Grazing incidence x-ray diffraction of CSS-CdS films grown with oxygen (670-550-5-2) and without oxygen (670-550-5-0).

Transmittance of CdS films in the visible region ranged from 80 to $90 \%$, for films deposited by both techniques, as can be seen by the spectra shown in Fig. 4a. It should be noted that the optical absorption edges were sharper in CSS films deposited without oxygen. Neglecting the reflectance at film/air and film/substrate interfaces, the absorption coefficient $(\alpha)$ of the CdS film at each wavelength $(\lambda)$ was obtained 
from the transmittance data using Equation 1, where $t$ is the thickness of the film, $T_{s}$ is the transmittance of the substrate (glass/SnO $\mathrm{Sn}_{2}$ ), and $T_{f, s}$ is the transmittance of the film/substrate system.

$$
\alpha(\lambda)=-\frac{1}{t} \ln \left[\frac{T_{f, s}}{T_{s}}\right]
$$

The direct optical bandgap was obtained from the linear portion of the $\alpha^{2}$ versus photon energy plot [13], as depicted in Fig. 4b. The values - $2.52 \mathrm{eV}$ (CBD films) and $2.44 \mathrm{eV}$ (CSS films, mean value) - are close to those found in the literature [3-5]. The higher bandgap energy represents an advantage for CBD films, since absorption losses in the blue region may be minimized.

(a)
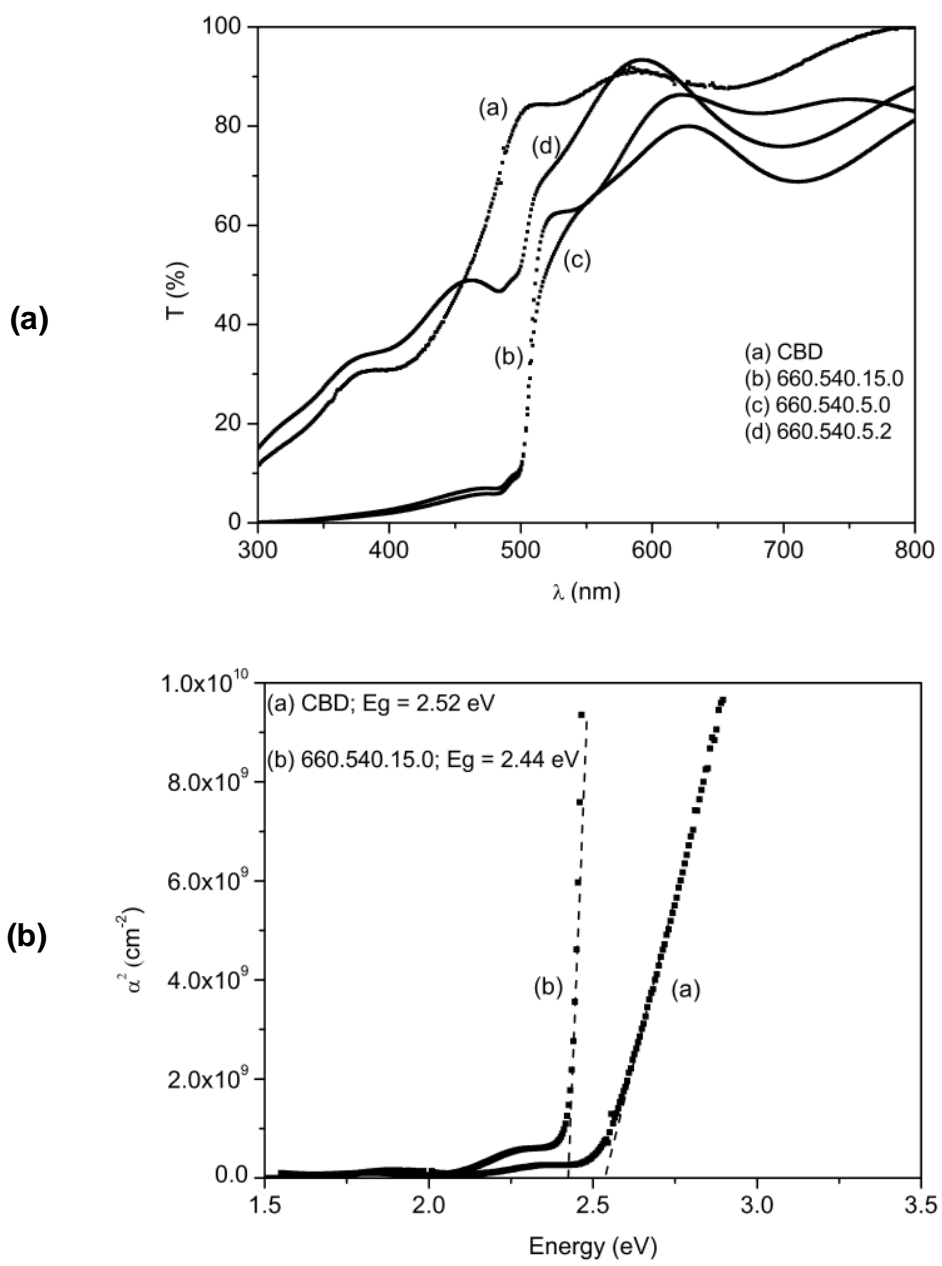

Figure 4: Optical properties of CBD and CSS-CdS films grown at different conditions: a) transmittance spectra; b) absorption coefficient versus photon energy for bandgap determination.

Table 3 shows photovoltaic parameters of the CdS/CdTe solar cells extracted from the current density (J) versus voltage (V) curves, as illustrated in Fig. 5. The results are a mean value of different areas of the same device, each one sizing roughly $0.5 \mathrm{~cm}^{2}$. The CBD and CSS-CdS films were deposited using the parameters shown in Tables 1 and 2, respectively. The CdTe film and the completed cell were manufactured as described in the experimental method. The larger grain size, better crystallinity, and sharper absorption edges observed in CSS-CdS films did not imply in better devices. Indeed, the efficiencies ( $n$ ) of CBD and CSSCdS solar cells were quite similar, around 5\%, except for the device CSS-CdS \# 660-540-5-2, which had its CdS film deposited under oxygen atmosphere. Although the literature reports that oxygen is beneficial to 
the cell (usually, CBD cells - in which oxygen is naturally incorporated from the bath - are more efficient than CSS cells) [6], our results showed that it dramatically impaired the value of the open circuit voltage (Voc). This decrease in Voc suggests that the oxygen has led to the formation of oxides at CdS/CdTe interface instead of playing its role of increasing the cell efficiency. The mechanism by which oxygen improves the cell performance is not very well understood. Some authors propose that the properties of the films are affected by the reaction between the oxygen and the other species in the chamber, such as $\mathrm{Cd}$, leading to the formation of cadmium oxide [12]. Such reaction changes the nucleation and growth kinetics of the CdS film, and hence its microstructure. Figure 2, which showed that a better coverage had been obtained when the CdS film was grown in an $\mathrm{O}_{2}$ atmosphere, confirms this proposition. The fill factor (FF) value of $40 \%$ was mainly limited by series resistances originated mostly from the back contact that generated a rectifier barrier at $\mathrm{Au} / \mathrm{CdTe}$ interface. The presence of this barrier was confirmed by the shape of the $\mathrm{J} \times \mathrm{V}$ curves in the first quadrant; it appeared as a saturation signal at voltages above Voc, a behavior commonly referred to as rollover (see Fig. 5). Shunt resistances were identified in a less extent and may have been caused by shunt paths generated, for example, by discontinuities in the very thin CdS layer. For instance, the rough and open grained morphology of CSS-CdS films compared to the more compact one of CBD-CdS films may have contributed to the shunting characteristics of the J-V curves.

Table 3: Photovoltaic parameters of $\mathrm{SnO}_{2} / \mathrm{CdS} / \mathrm{CdTe}$ solar cells: short circuit current density (Jsc); open circuit voltage (Voc); fill factor (FF); solar efficiency $(\eta)$.

\begin{tabular}{|c|c|c|c|c|}
\hline CdS LAYER & $\begin{array}{c}\mathrm{J}_{\mathrm{sc}} \\
\left(\mathrm{mA} \cdot \mathrm{cm}^{-2}\right)\end{array}$ & $\begin{array}{l}\mathrm{V}_{\mathrm{oc}} \\
(\mathrm{mV})\end{array}$ & $\begin{array}{l}\text { FF } \\
(\%)\end{array}$ & $\begin{array}{c}\eta \\
(\%)\end{array}$ \\
\hline CBD-CdS \#3 & 18.9 & 627.9 & 40.4 & 4.8 \\
\hline CSS-CdS \# 660-540-15-0 & 21.5 & 567.2 & 42.2 & 5.2 \\
\hline CSS-CdS \# 660-540-5-0 & 18.8 & 582.4 & 44.2 & 4.8 \\
\hline CSS-CdS \# 660-540-5-2 & 18.6 & 391.0 & 41.2 & 3.0 \\
\hline
\end{tabular}

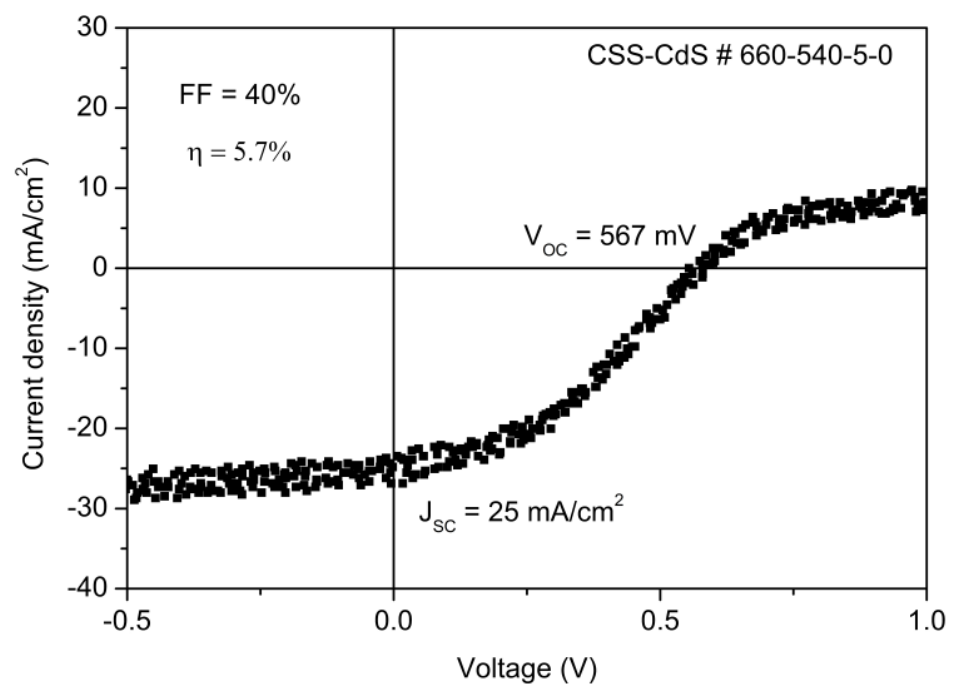

Figure 5: J x V curve of a CdS/CdTe solar cell.

\section{CONCLUSION}

The time for depositing CdS thin films by CBD was longer than that required by CSS. However, it was easier to get thinner films by CBD technique. Transmittance of both CBD and CSS films were quite similar, but the bandgap in CSS was narrower than in CBD films, which means that CSS films transmit less of the blue part of the solar spectrum to the CdTe absorber layer than CBD films. Although microstructures of CBD (nanocrystalline) and CSS (crystalline) films were quite different, the solar efficiencies of the CdS/CdTe devices were in the same range (5\%). This result shows that it may be advantageous to grow CdS films in CSS systems, because the CdS/CdTe device may be fully manufactured inside the same equipment. 


\section{ACKNOWLEDGMENTS}

This work was supported by CENPES-PETROBRAS.

\section{BIBLIOGRAPHY}

[1] WALDAU, A. J., "Thin Film Photovoltaics: Markets and Industry", International Journal of Photoenergy, Review Article (2012), Article ID 768368, 6 pages. doi:10.1155/2012/768368.

[2] GREEN, M.A., EMERY, K., HISHIKAWA, Y., et al., "Solar Cells Efficiency Tables (version 42)", Progress in Photovoltaics: Research and Applications, v. 21, pp. 827-837, 2013.

[3] MENDOZA-PEREZ, R., SANTANA-RODRIGUEZ, G., SASTRE-HERNANDEZ, J., et al., "Effects of thiourea concentration on CdS thin films grown by chemical bath deposition for CdTe solar cells", Thin Solid Films, v. 480-481, pp. 173-176, 2005.

[4] WENYI, L., XUN, C., QIULONG, C., et al., "Influence of growth process on the structural, optical and electrical properties of CBD-CdS films", Materials Letters, v. 59, pp. 1-5, 2005.

[5] MAHDI, M.A., HASSAN, Z., NG, S.S., et al., "Structural and optical properties of nanocrystalline CdS thin films prepared using microwave-assisted chemical bath deposition", Thin Solid Films, v. 520, pp. 34773484, 2012.

[6] MOUTINHO, H.R., ALBIN, D., YAN, Y., et al., "Deposition and properties of CBD and CSS CdS thin films for solar cell application", Thin Solid Films, v. 436, pp. 175-180, 2003.

[7] SCHAFFNER, J., FELDMEIER, E., SWIRSCHUK, A., et al., "Influence of substrate temperature, growth rate and TCO substrate on the properties of CSS deposited CdS thin films", Thin Solid Films, v. 519, pp. 7556-7559, 2011.

[8] FELDMEIER, E.M., FUCHS, A., SCHAFFNER, J., et al., "Comparison between the structural, morphological and optical properties of CdS layers prepared by Close Space Sublimation and RF magnetron sputtering for CdTe solar cells", Thin Solid Films, v. 519, pp. 7596-7599, 2011.

[9] PINHEIRO, W.A., FALCÃO, V.D., CRUZ, L.R., et al., "Comparative Study of CdTe Sources Used for Deposition of CdTe Thin Films by Close Spaced Sublimation Technique", Materials Research, v. 9, n.1, pp. 47-49, 2006.

[10] PINHEIRO, W.A., FERNANDES, J.A.S., CABOCLO, G.D., et al., "Fabrication of TCO/CdS/CdTe/Au solar cells using different $\mathrm{CdCl}_{2}$ treatments", In: Proceedings of the 33rd IEEE Photovoltaic Specialists Conference, pp.1-4, San Diego, CA, 2008.

[11] SOSA, V. CASTRO, R., PEÑA, J.L., "Pressure and temperature influence on CdTe thin-film deposited by close-spaced vapor transport technique", Journal of Vacuum Science and Technology, v. A8, n.2, pp. 979983, 1990.

[12] CONTRERAS-PUENTE, G., VIGIL-GALÁN, O., VIDAL-LARRAMENDI, J., et al., "Influence of the growth conditions in the properties of the CdTe thin films deposited by CSVT", Thin Solid Films, v. 387, pp. 50-53, 2001.

[13] FAHRENBRUCH, A.L., BUBE, R.H., Fundamentals of Solar Cells, 1ed., New York, Academic Press, 1983. 